\title{
28. MIDDLE AND LATE EOCENE PLANKTONIC FORAMINIFERA FROM THE NORTHWESTERN PACIFIC, LEG 32 OF THE DEEP SEA DRILLING PROJECT
}

\author{
Monique Toumarkine, Swiss Federal Institute of Technology, Zurich, Switzerland
}

\section{INTRODUCTION}

During Leg 32, middle and late Eocene planktonic foraminifera were recovered at three sites: Site 305 (Shatsky Rise), Site 310 (Hess Rise), and Site 313 (northeastern Mid-Pacific Mountains).

In general, the tests of the planktonic foraminifera are more or less strongly affected by dissolution, and it is therefore difficult to establish a zonation, particularly at Site 310 where only a very reduced number of species are preserved.

The zonation adopted in this paper is the same as in Bolli $(1966,1972)$ and in Saunders et al. (1973). In addition, use has been made of the evolution of representatives of the genus Globigerinatheka (Proto-Decima and Bolli, 1970; Bolli, 1972) which are well represented at Sites 305 and 313, and of the evolutionary lineage of the subspecies of Globorotalia cerroazulensis (Toumarkine and Bolli, 1970).

Although the presence of some zones could be established at Sites 305 and 313, none of the three sites represents a complete sequence of the middle and late Eocene.

The figured specimens are deposited at the Museum of Natural History, Basel, under the numbers C 30401 to C 30494 .

\section{SITE 305-SHATSKY RISE}

(lat $32^{\circ} 00.13^{\prime} \mathrm{N}$, long $157^{\circ} 51.00^{\prime} \mathrm{E}$, water depth $2903 \mathrm{~m}$ )

At Site 305, middle and late Eocene microfaunas are found in Core 10 and part of Core 9 (Table 1). The corecatcher sample of Core 10 contains numerous representatives of the genus Globigerinatheka (mainly G. mexicana mexicana, $G$. mexicana barri, and $G$. index index). The sample is attributed to the middle part of the middle Eocene because these subspecies of the genus Globigerinatheka have their first appearances only in the Globigerinatheka subconglobata subconglobata Zone ( $G$. index index within the upper part of this zone). The sample could also be placed into the Globorotalia lehneri Zone or even into a younger zone. The specimens of Globorotalia aragonensis found in the same sample must be reworked from the lower Eocene because they occur together with such typical early Eocene species as Globorotalia soldadoensis, G. caucasica, and G. quetra. The other species found in the core-catcher sample of Core 10 have a long-ranging stratigraphic distribution which in many cases includes the entire middle Eocene (Globorotalia spinulosa, G. spinuloinflata, G. bullbrooki, G. broedermanni, Truncorotaloides topilensis, T. rohri) or even extends into the late Eocene (Globigerina linaperta, G. eocaena, G. senni, G. cryptomphala, $G$. venezuelana, $G$. hagni, Globigerinita pera, Globigerinita sp.).
The next-higher samples (from Samples 10-5, 118-120 $\mathrm{cm}$, to $10-5,18-20 \mathrm{~cm}$ ) still belong to the middle Eocene (presence of spinose species such as Globorotalia spinuloinflata, $G$. bullbrooki, G. lehneri). In these samples, Globorotalia cerroazulensis pomeroli and Globigerinatheka index rubriformis appear for the first time. Reworked early Eocene species are also present. Dissolution effects are rather strong and are probably responsible for the impoverished assemblages.

Starting with Sample 10-4, 20-22 cm, spinose forms are absent except rare specimens which are evidently reworked from the middle Eocene (mainly Truncorotaloides rohri). In addition to species already present in the middle Eocene, the microfaunas contain Hantkenina alabamensis, fragments of Cribrohantkenina sp., Globorotalia cerroazulensis cerroazulensis and G. cerroazulensis cocoaensis (very rare), Globigerina tripartita, $G$. gortanii praeturritilina, G. officinalis, G. galavisi, Globorotaloides sp. cf. G. suteri, Globigerinatheka index tropicalis, and G. subconglobata luterbacheri. The corecatcher sample of Core 9 has furnished very rare and small specimens of Globigerinatheka semiinvoluta.

The samples between Samples 10-4, 20-22 cm, and 9$3,70-72 \mathrm{~cm}$, are attributed to the late Eocene based on negative evidence (absence of spinose forms) and positive evidence (presence of species restricted to the late Eocene such as Globigerinatheka semiinvoluta, Globorotalia cerroazulensis cocoaensis, Cribrohantkenina sp., or of species having their main occurrence within this subepoch, e.g., Globigerinatheka index tropicalis, G. subconglobata luterbacheri, Globorotalia cerroazulensis cerroazulensis).

The exact position of the limit between the Globigerinatheka semiinvoluta Zone and the Globorotalia cerroazulensis cerroazulensis Zone is difficult to establish because the dissolution of planktonic foraminiferal tests is very strong. Starting with Sample 9-6, 18-20 cm, the microfaunas contain almost no planktonic foraminifera. The youngest specimen of Globigerinatheka subconglobata luterbacheri has been observed in Sample 9-6, $18-20 \mathrm{~cm}$, and this sample may therefore still be attributed to the Globigerinatheka semiinvoluta Zone. However, most of the constituents of this faunule are reworked from the middle Eocene, and it is therefore possible that this single specimen could also be displaced.

The Eocene-Oligocene boundary is situated between Sample 9-3, 70-72 cm and 9-2, 136-138 cm. In Sample 9$3,70-72 \mathrm{~cm}$, a few fragments of Hantkenina sp. and Cribrohantkenina sp. are observed, whereas Sample 9-2, $136-138 \mathrm{~cm}$ contains an exclusively Oligocene assemblage.

At Site 305 , it is very possible that the lower part of the middle Eocene is missing. Sample 11-1, 38-48 cm still 
TABLE 1

Distribution of Planktonic Foraminifera in Cores 9 to 10, Site 305, DSDP Leg 32

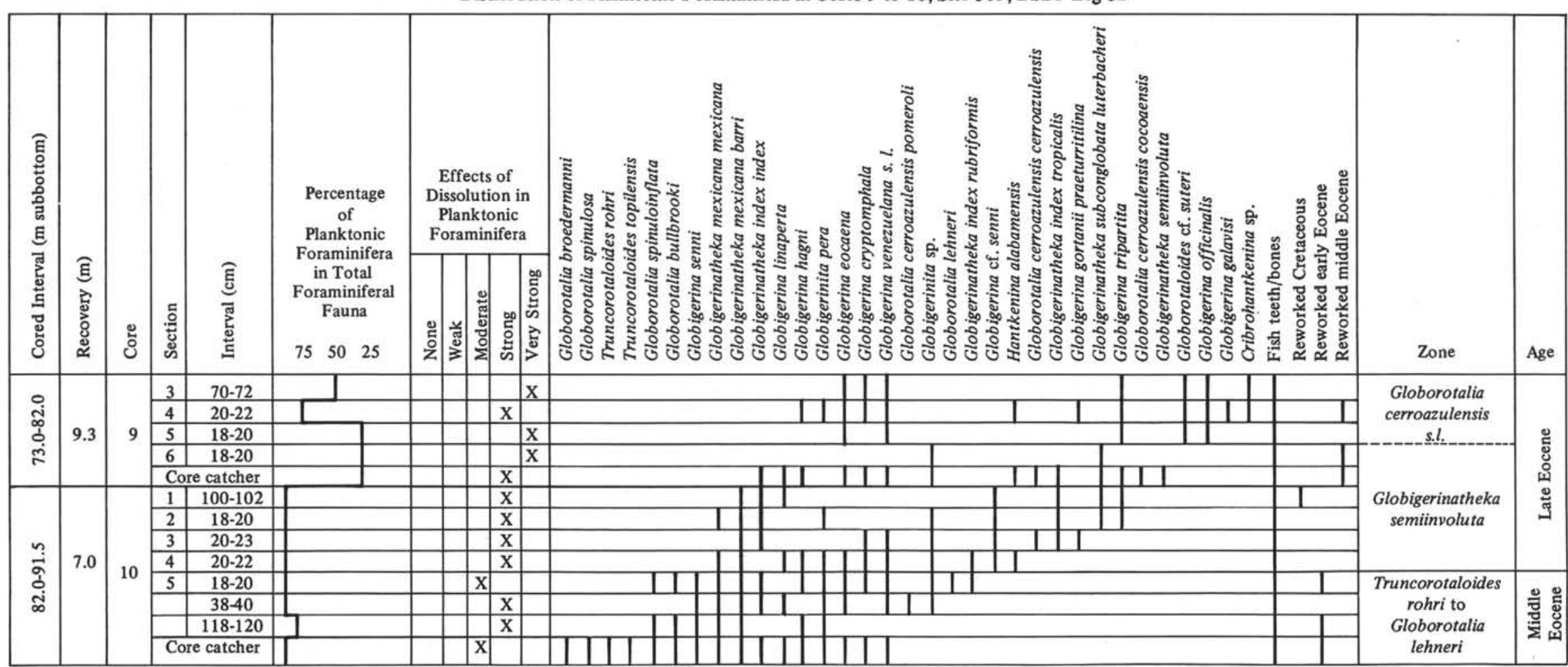


TABLE 2

Distribution of Planktonic Foraminifera in Core 11 Site 310, DSDP Leg 32

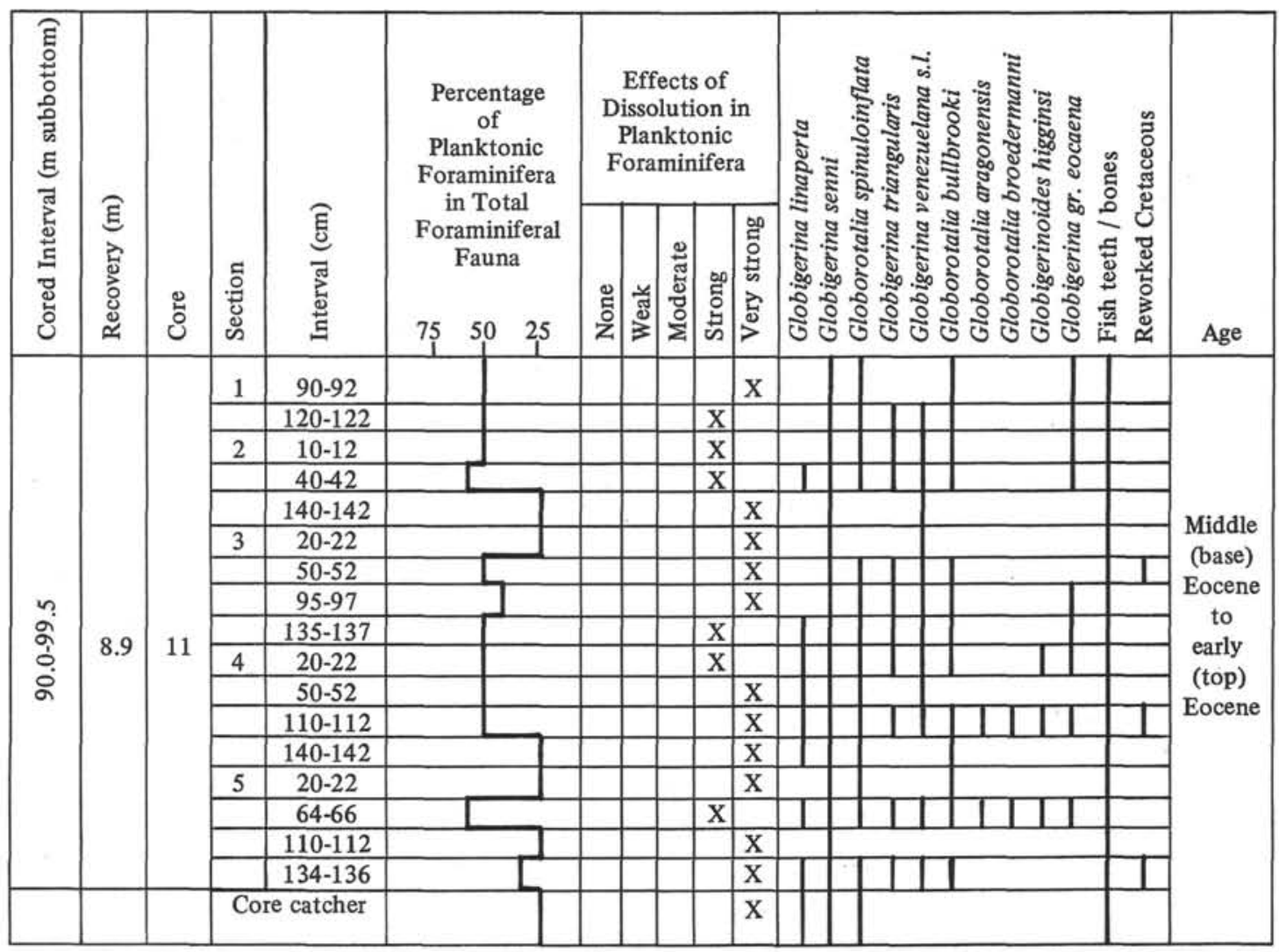

belongs to the early Eocene, whereas the core-catcher sample of Core 10 is placed in at least the middle part of the middle Eocene. A very low rate of sedimentation would be required in order to accommodate the entire lower part of the middle Eocene into the topmost $38 \mathrm{~cm}$ of Core 11 (which has not been sampled) and the intervals for which no sediment was recovered (Core 10: 9.5 $\mathrm{m}$ cored, $7.0 \mathrm{~m}$ recovered; Core $11: 9.5 \mathrm{~m}$ cored, $8.8 \mathrm{~m}$ recovered). The absence or very reduced thickness of the interval, corresponding to the two lowermost biozones of the middle Eocene, may be the result of very strong dissolution which destroyed the calcareous tests before or during their deposition.

\section{SITE 310-HESS RISE}

(lat $36^{\circ} 52.11^{\prime} \mathrm{N}$, long $176^{\circ} 54.09^{\prime} \mathrm{E}$, water depth $3516 \mathrm{~m}$ )

The very strong effects of dissolution on the planktonic foraminiferal tests prevent the recognition of any biozones. The intensive calcium carbonate dissolution is recognized here by the concentration of zeolites and fish remains (teeth and scales) in the washed residues, typical for deposition below the calcium carbonate compensation depth.

It is even difficult to decide whether the samples from the single core studied (Core 11) can be correlated to the early or middle Eocene. The Maestrichtian, Paleocene, at least parts of the early and middle Eocene and the late Eocene are not represented at Site 310 because Core 12 is of Campanian age and Core 10 contains an Oligocene microfauna.

The few species persisting in Core 11 (Table 2) are not very age specific and are known from the upper part of the early Eocene as well as from the middle Eocene. They are mainly: Globigerina linaperta, G. senni, G. eocaena, G. triangularis, G. venezuelana, Globorotalia bullbrooki, G. spinuloinflata; G. broedermanni, G. aragonensis, and Globigerinoides higginsi. The part of the Eocene present at Site 310 is close to the boundary between the early and middle Eocene. It can be placed either into the uppermost part of the early Eocene or at most into the basal part of the middle Eocene, as suggested by the absence of the dissolution-resistant globular tests of Globigerinatheka.

\section{SITE 313-NORTHEASTERN MID-PACIFIC MOUNTAINS} (lat $20^{\circ} 10.52^{\prime} \mathrm{N}$, long $170^{\circ} 57.15^{\prime} \mathrm{W}$, water depth $3484 \mathrm{~m}$ )

The middle Eocene of Site 313 is of great interest because it allows a study of the effects of selective dissolution in planktonic foraminiferal assemblages. Samples strongly affected by dissolution alternate with others in which a considerable number of species persists.

Unfortunately, bad weather conditions caused disturbed cores with mixed faunas. In addition, reworking of older microfaunas is frequent. Some samples contain mixtures of Cretaceous, Paleocene, early Eocene, middle 
TABLE 3

Distribution of Planktonic Foraminifera in Cores 5 to 7, Site 313, DSDP Leg 32

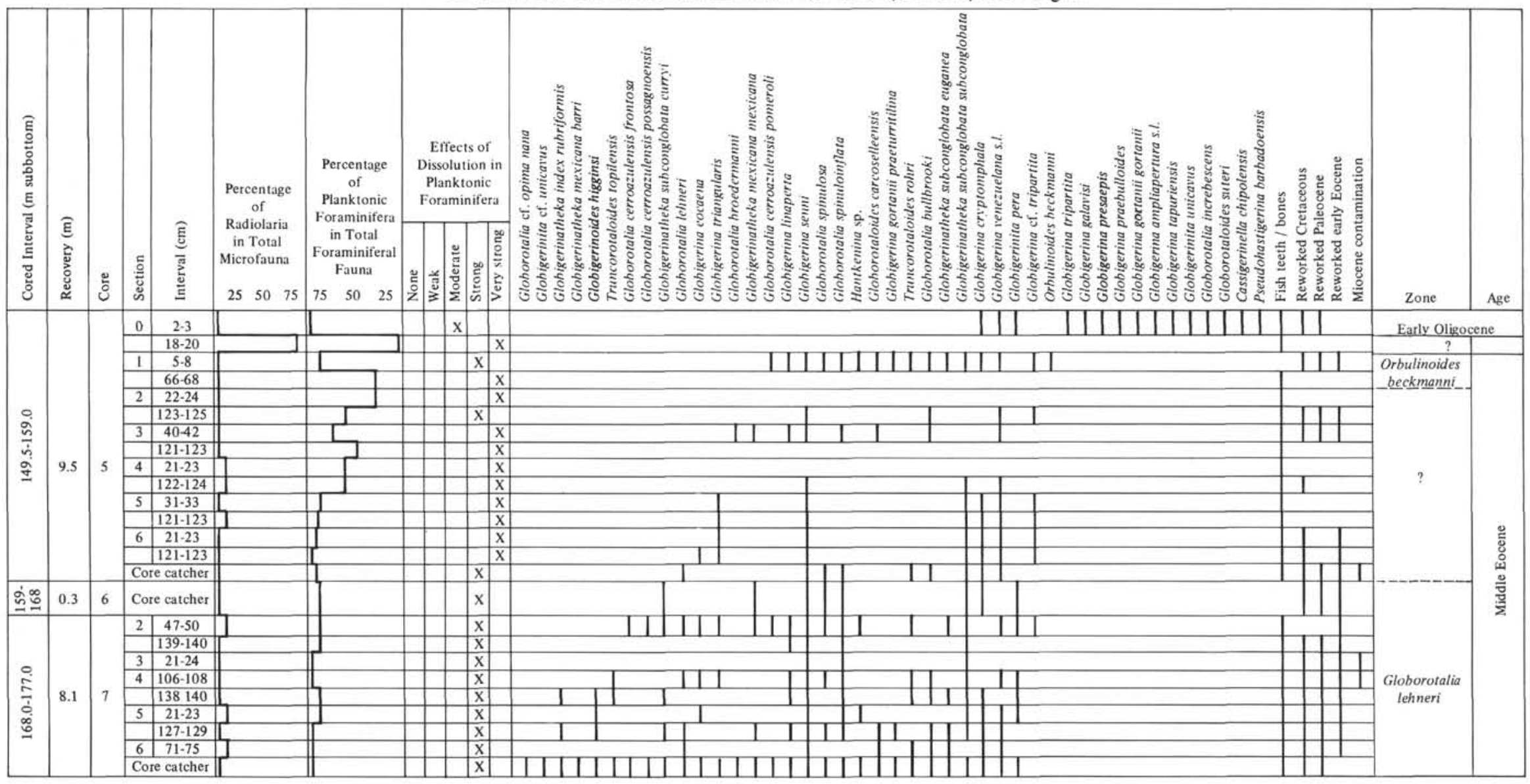


Eocene, and Neogene microfaunas (Table 3). However, the study of the samples in sequence and the age determinations based on calcareous nannoplankton indicate that Cores 7,6, and 5 (except the top of Core 5 which is of Oligocene age) are of middle Eocene age.

In some samples the reworked specimens constitute a major part of the microfauna, and they are better preserved than those in place (especially those of Cretaceous age). Late Cretaceous planktonic foraminifera are represented by excellently preserved globotruncanids and rugoglobigerinids. Possibly the entire Paleocene is represented in the reworked microfaunas; at least its following zones could be recognized: Globorotalia pseudobulloides Zone, Globorotalia uncinata Zone, Globorotalia pseudomenardii Zone, Globorotalia velascoensis Zone as evidenced by the presence of Globigerina triloculinoides, $G$. primitiva, Globorotalia pseudobulloides, G. uncinata, G. pusilla pusilla, G. pusilla laevigata, $G$. pseudomenardii, G. chapmani, $G$. aequa, and $G$. velascoensis. The early Eocene Globorotalia subbotinae Zone and Globorotalia aragonensis Zone are indicated by Globorotalia subbotinae, G. aragonensis, G. esnaensis, $G$. soldadoensis, and $G$. quetra.

The lowermost sample studied (core-catcher sample of Core 7) belongs to the Globorotalia lehneri Zone of the middle Eocene. Zonal attributions are based on the evolutionary lineages of Globorotalia cerroazulensis and of Globigerinatheka, especially of the sequence Globigerinatheka subconglobata curryi-G. subconglobata euganea-Orbulinoides beckmanni. The sample contains Globorotalia cerroazulensis frontosa, G. cerroazulensis possagnoensis, and $G$. cerroazulensis pomeroli. According to sections studied in Italy and the Caribbean (Toumarkine and Bolli, 1970) the co-occurrence of these subspecies is restricted to the uppermost part of the Globorotalia lehneri Zone. In addition, the same sample has furnished Globigerinatheka subconglobata curryi and $G$. subconglobata euganea which, according to ProtoDecima and Bolli (1970), coexist in the sections studied in Italy and the Caribbean only with the Globorotalia lehneri Zone. This sample also contains the following species: Globigerina linaperta, G. senni, G. eocaena, $G$. venezuelana s.l., G. cryptomphala, Globigerina sp. cf. $G$. gortanii praeturritilina, $G$. triangularis, Globigerina sp. aff. G. tripartita, Globorotalia lehneri, G. spinulosa, G. spinuloinflata, $G$. bullbrooki, $G$. broedermanni, $G$. opima nana, Globigerinatheka subconglobata subconglobata, $G$. mexicana mexicana, $G$. mexicana barri, $G$. index rubriformis, Globigerinita pera, Globigerinita sp. cf. G. unicavus, Globorotaloides carcoselleensis, Globigerinoides higginsi, Hantkenina sp., Truncorotaloides rohri, and T. topilensis. All of these species are well known from this part of the middle Eocene.

The next younger samples are strongly affected by dissolution and are therefore less rich. Nevertheless, the coexistence of the same subspecies of Globorotalia cerroazulensis and of Globigerinatheka subconglobata in Sample 7-2, 47-50 cm still indicates the Globorotalia lehneri Zone. Above this sample, the effects of dissolution increase and only a few of the most resistant species persist. Some washed residues contain no planktonic foraminifera at all and are dominated by fish teeth and scales.
The next, stratigraphically higher, section is again an interval with better preserved and richer microfaunas (Sample 5-1, 5-8 cm). This sample contains three good specimens of Orbulinoides beckmanni together with numerous Globigerinatheka subconglobata euganea. Orbulinoides beckmanni is an excellent index fossil and is restricted to the homonymous zone. As is usual in this zone, Globorotalia cerroazulensis is only represented by rare specimens of its subspecies pomeroli.

At Site 313, two middle Eocene zones can be identified, but their limits cannot be defined because the characteristic samples are separated by intervals strongly affected by dissolution in which the index species are destroyed.

The sample attributed to the Orbulinoides beckmanni Zone is immediately overlain by an interval which is almost completely devoid of planktonic as well as benthonic foraminifera. The washed residues are almost completely composed of Radiolaria and sponge spicules.

A sample taken $15 \mathrm{~cm}$ higher (Sample 5-0, 2-3 cm) furnished a good microfauna which is completely different from the next older one. It contains Globigerina tripartita, G. praesaepis, G. galavisi, G. praebulloides, G. gortanii gortanii, G. ampliapertura s.1., G. tapuriensis, Globigerinita unicavus, Globorotalia increbescens, Globorotaloides suteri, and also Globigerina venezuelana s.1. and $G$. cryptomphala which persist from the middle Eocene. These large globigerinids are found together with numerous Cassigerinella chipolensis and Pseudohastigerina barbadoensis which indicate an early Oligocene age (Plate 3 ).

Between the top of the middle Eocene and the base of the Oligocene, dissolution effects are very strong and have eliminated virtually all calcareous tests. The entire interval is represented by a thin layer with only siliceous microfossils.

\section{REMARKS ON THE GEOGRAPHIC AND STRATIGRAPHIC DISTRIBUTION OF THE GENUS GLOBIGERINATHEKA (PLATE 4)}

The specific composition of the representatives of Globigerinatheka found at Sites 305 and 313 is partly different. Because part of the samples are age equivalent (late middle Eocene), it is possible that the compositional difference may be the result of the difference in latitude between the two sites (Site 305 approximately $32^{\circ} \mathrm{N}$, Site 313 approximately $20^{\circ} \mathrm{N}$ ). Similar differences in the latitudinal distribution of the species and subspecies of Globigerinatheka are discussed by Bolli (1972). The subspecies $G$. mexicana mexicana and $G$. mexicana barri are common to both sites. Both subspecies have been found by Bolli (1972) in the Caribbean (tropical) and Italy (temperate).

$G$. index index occurs only in the more northerly Site 305 , whereas the evolutionary lineage $G$. subconglobata curryi-G. subconglobata euganea-Orbulinoides beckmanni is well represented at Site 313 . The subspecies $G$. index index is typical for the temperate climatic zone. It is found in Europe in the Alps and the Mediterranean region (e.g., Bolli, 1972); in the southern hemisphere in New Zealand (e.g., Jenkins, 1971); and in cores taken 
between $37^{\circ}$ and $40^{\circ} \mathrm{S}$ (Margolis and Kennett, 1971). The evolutionary lineage leading to Orbulinoides beckmanni is always better represented in tropical latitudes (Proto-Decima and Bolli, 1970; Bolli, 1972). Site 313 also contains $G$. subconglobata subconglobata, a species not found at Site 305 although, according to published data, this species is typical for areas with temperate climate. Representatives of $G$. index rubriformis, a subspecies considered to be typically temperate, occur at both sites.

The late Eocene samples from Site 305 contain the temperate subspecies $G$. subconglobata luterbacheri together with $G$. index tropicalis which has a much wider geographic range. In this site other small forms close to $G$. semiinvoluta occur.

Thus, at Site 305 , which is temperate, species occur which are specific to this latitude (with the exception of $G$. subconglobata subconglobata, which is absent). The composition of the representatives of Globigerinatheka at Site 313 is typical for a transition between tropical and temperate assemblages. Typically tropical species and subspecies are associated with such temperate subspecies as $G$. index rubriformis and $G$. subconglobata subconglobata, which are here more abundant and better developed at Site 313 than in typically tropical assemblages.

\section{REMARKS ON DISSOLUTION EFFECTS} (PLATE 5)

As demonstrated by previous and more detailed investigations (e.g., Cita, 1970; Premoli-Silva and Bolli, 1973), the most dissolution-resistant forms among the planktonic foraminifera have a compact and thick test. Typical examples of such a morphology are Globigerina senni and Globorotalia spinuloinflata, which dominate the Eocene microfaunas at Site 310.

The effects of dissolution are also visible in the tests of the resistant species: the walls of the tests are etched, selective dissolution of individual crystals is observed, the size of the pores is enlarged, spines become more pronounced (Plate 5, Figures 1-13), and the umbilicus is enhanced. In some Globorotalia the initial spire is corroded and the embryonic chambers may become visible (Plate 5, Figures 12, 14). With increasing dissolution the pores of Globigerina species become more distinct and enlarged. The larger crystals surrounding the pores are more resistant to dissolution than those in the interior of the pores and than those forming the surface of the test between the pores. The surface of the tests of these etched Globigerina looks as if it is covered by funnelshaped pustules (Plate 5, Figures 17-20). Often the tests appear to have been scoured, the large crystals forming the cortex are dissolved and only narrow bands enhancing the sutures are preserved (e.g., Globorotalia increbescens at Site 313 ). In this case, the crystals in the depressions of the surface might be better protected against dissolution (Plate 5, Figure 15).

With even more progressive dissolution, the tests become perforated and then fragmented. Very often only the outer walls are preserved, whereas the more delicate inner chambers are completely dissolved. As pointed out by Cita (1970), coccolith tests are more dissolution resistant than those of planktonic foraminifera. Well-preserved coccolith tests may be observed between the more or less dissolved crystals of the tests of globigerinids, although coccolith tests are built of considerably finer crystals (Plate 5 , Figures $7,8,11,13$ ).

\section{ACKNOWLEDGMENTS}

The middle and late Eocene samples collected during DSDP Leg 32 were made available by H.P. Luterbacher. H.M. Bolli has critically read the manuscript and given much help and advice during the study of the samples. Some of the aspects involved were discussed with K. Perch-Nielsen, J.P. Beckmann, and F. Rögl. The scanning electron scope micrographs were provided by H.E. Franz. To all of them I want to express my sincere thanks.

\section{REFERENCES}

Baumann, P., 1970. Micropaläontologische und stratigraphische Untersuchungen der obereozănen-oligozănen Scaglia im Zentral Apennin (Italien): Eclog. Geol. Helv., v. 63, p. 1133.

Blow, W.H., 1969. Late middle Eocene to Recent planktonic foraminiferal biostratigraphy: Internatl. Conf. Plankt. Microfossils, Proc., 1st, Geneva, 1967, v. 1, p. 199.

Bolli, H.M., 1957. Planktonic foraminifera from the Eocene Navet and San Fernando formations of Trinidad, B.W.I.: U.S. Nat. Mus. Bull., v. 215, p. 97.

, 1966. Zonation of Cretaceous to Pliocene marine sediments based on planktonic foraminifera: Assoc. Venezolana Geol. Mineral. Petrol., v. 9, p. 3.

1972. The genus Globigerinatheka Broennimann: J. Foram. Res., v. 2, p. 109.

Cita, M.B., 1970. Observations sur quelques aspects paléogéoécologiques de sondages subocéaniques effectués dans l'Atlantique Nord: Rev. Micropaléontol., v. 12, p. 187.

Jenkins, D.G., 1971. New Zealand Cenozoic planktonic foraminifera: New Zealand Geol. Survey, Paleontol. Bull. 42.

Margolis, S.V. and Kennett, J.P., 1971. Cenozoic paleoglacial history of Antarctica recorded in Subantarctic deep-sea cores: Am. J. Sci., v. 271, p. 1.

Premoli-Silva, I. and Bolli, H.M., 1973. Late Cretaceous to Eocene planktonic foraminifera and stratigraphy of Leg 15 sites in the Caribbean Sea. In Edgar, N.T., Saunders, J.B., et al., Initial Reports of the Deep Sea Drilling Project, Volume 15: Washington (U.S. Government Printing Office), p. 449.

Proto-Decima, F. and Bolli, H.M., 1970. Evolution and variability of Orbulinoides beckmanni (Saito): Eclog. Geol. Helv., v. 63 , p. 885 .

Saunders, J.B., Beaudry, F.M., Bolli, H.M., Rögl, F., Riedel, W.R., Sanfilippo, A., Premoli-Silva, I., 1973. Paleocene to Recent microfossil distribution in the marine and land areas of the Caribbean. In Edgar, N.T., Saunders, J.B., et al., Initial Reports of the Deep Sea Drilling Project, Volume 15: Washington (U.S. Government Printing Office), p. 769-772.

Toumarkine, M. and Bolli, H.M., 1970. Evolution de Globorotalia cerroazulensis (Cole) dans l'Eocène moyen et supérieur de Possagno (Italie): Rev. Micropaléontol., v. 13, p. 131. 


\section{PLATE 1}

Figures 1, 2 Globigerina linaperta Finlay, $\times 100$.

Sample 313-7, CC. Globorotalia lehneri Zone; middle Eocene.

1. Spiral view (C 30 401).

2. Umbilical view (C 30 402).

Figures 3, $4 \quad$ Globigerina triangularis White, $\times 100$.

Sample $310-11-1,120-122 \mathrm{~cm}$. Early to middle Eocene.

3. Spiral view (C 30403 ).

4. Umbilical view (C 30 404).

Figure $5 \quad$ Globigerina cryptomphala Glaessner, $\times 75$.

Sample 313-7, CC. Globorotalia lehneri Zone; middle Eocene. Side view (C 30 405).

Figure $6 \quad$ Globigerina gortanii praeturritilina Blow and Banner, $\times 75$.

Sample 313-7, CC. Globorotalia lehneri Zone; middle Eocene. Side view (C 30 406).

Figures 7,8 Globigerina hagni Gohrbrandt.

Sample 305-10, CC. Globorotalia lehneri to Truncorotaloides rohri zones; middle Eocene.

7. Spiral view (C 30407$), \times 75$.

8. Umbilical view (C 30408$), \times 50$.

Figure $9 \quad$ Globigerinita pera (Todd), $\times 75$.

Sample 305-10, CC. Globorotalia lehneri to Truncorotaloides rohri zones; middle Eocene.

Umbilical view (C 30 409).

Figures 10,11 Truncorotaloides rohri Broennimann and Bermudez, $\times 100$.

Sample 313-7, CC. Globorotalia lehneri Zone; middle Eocene.

10. Spiral view (C 30410 ).

11. Umbilical view (C 30411 ).

Figures 12,13 Truncorotaloides topilensis (Cushman), $\times 100$.

12. Sample 313-7, CC. Globorotalia lehneri Zone; middle Eocene. Spiral view (C 30 412).

13. Sample $313-7-4,106-108 \mathrm{~cm}$. Globorotalia lehneri Zone; middle Eocene. Umbilical view (C 30413 ).

Figure 14 Globorotalia opima nana Bolli, $\times 100$.

Sample 313-7, CC. Globorotalia lehneri Zone; middle Eocene. Umbilical view (C 30 414).

Figure $15 \quad$ Hantkenina alabamensis Cushman, $\times 100$.

Sample 305-9, CC. Globigerinatheka semiinvoluta Zone; late Eocene (C 30 415).

Figures 16,17 Globigerinoides higginsi Bolli.

Sample 313-7, CC. Globorotalia lehneri Zone; middle Eocene.

16. Spiral view (C 30416$), \times 50$.

17. Umbilical view (C 30417 ), $\times 100$.

Figures 18, 19 Globorotaloides suteri Bolli, $\times 100$.

Sample 313-7, CC. Globorotalia lehneri Zone; middle Eocene.

18. Spiral view (C 30418 ).

19. Umbilical view (C 30 419).

Figures 20,21 Globorotaloides carcoselleensis Toumarkine and Bolli. $\times 100$.

Sample 313-7, CC. Globorotalia lehneri Zone; middle Eocene.

20. Spiral view (C 30420 ).

21. Umbilical view (C 30 421). 
PLATE 1
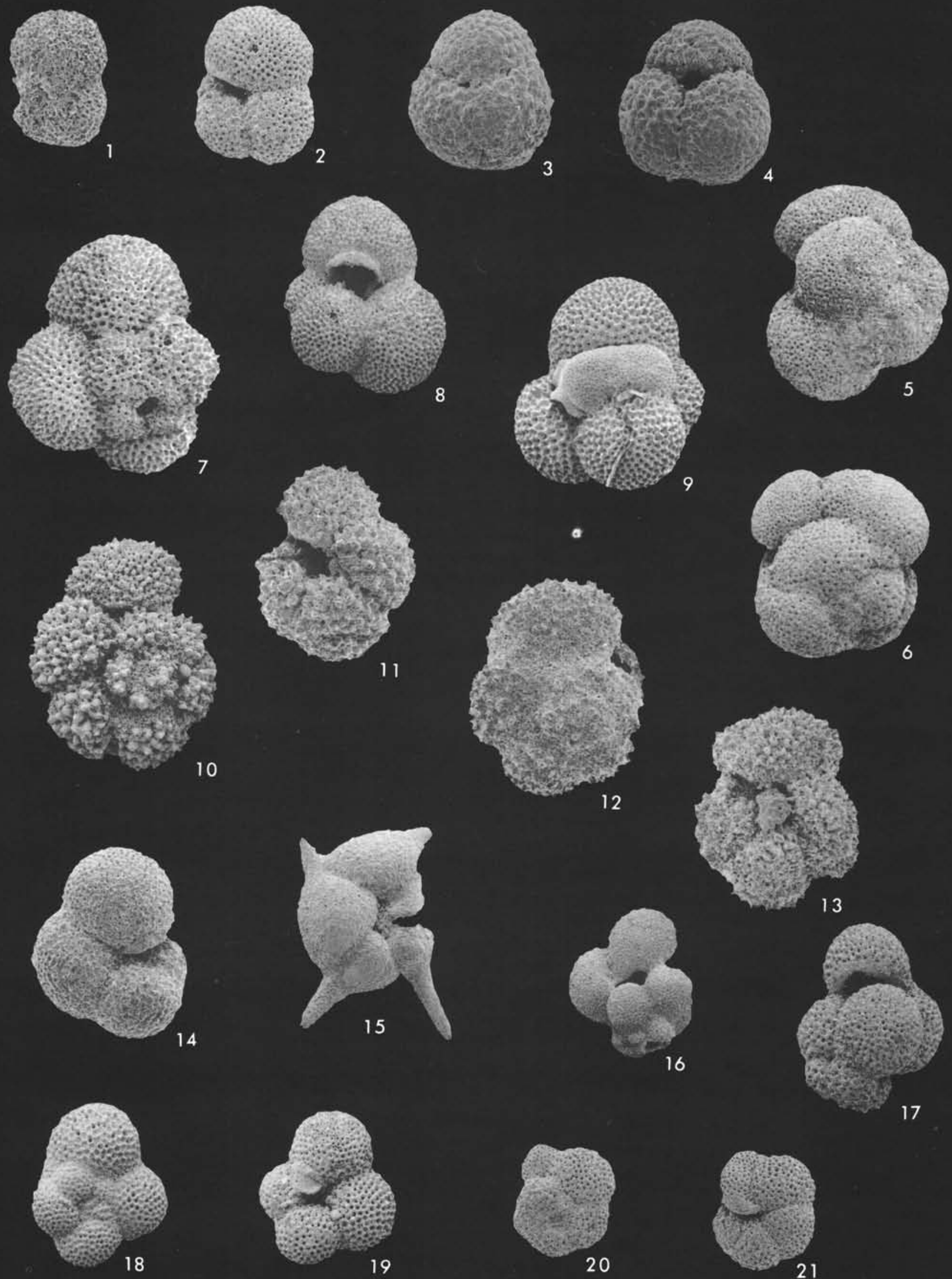


\section{PLATE 2}

Figure 1

Figures 2, 3

Figures 4,5

Figure 6

Figure 7

Figure 8

Figures 9, 10

Figures 11, 12

Figures 13, 14

Figures 15, 16

Figures 17, 18 Globorotalia broedermanni Cushman and Bermudez, $\times 100$.

Sample 313-7, CC. Globorotalia lehneri Zone; middle Eocene.

17. Spiral view (C 30438 ).

18. Umbilical view (C 30439 ). 


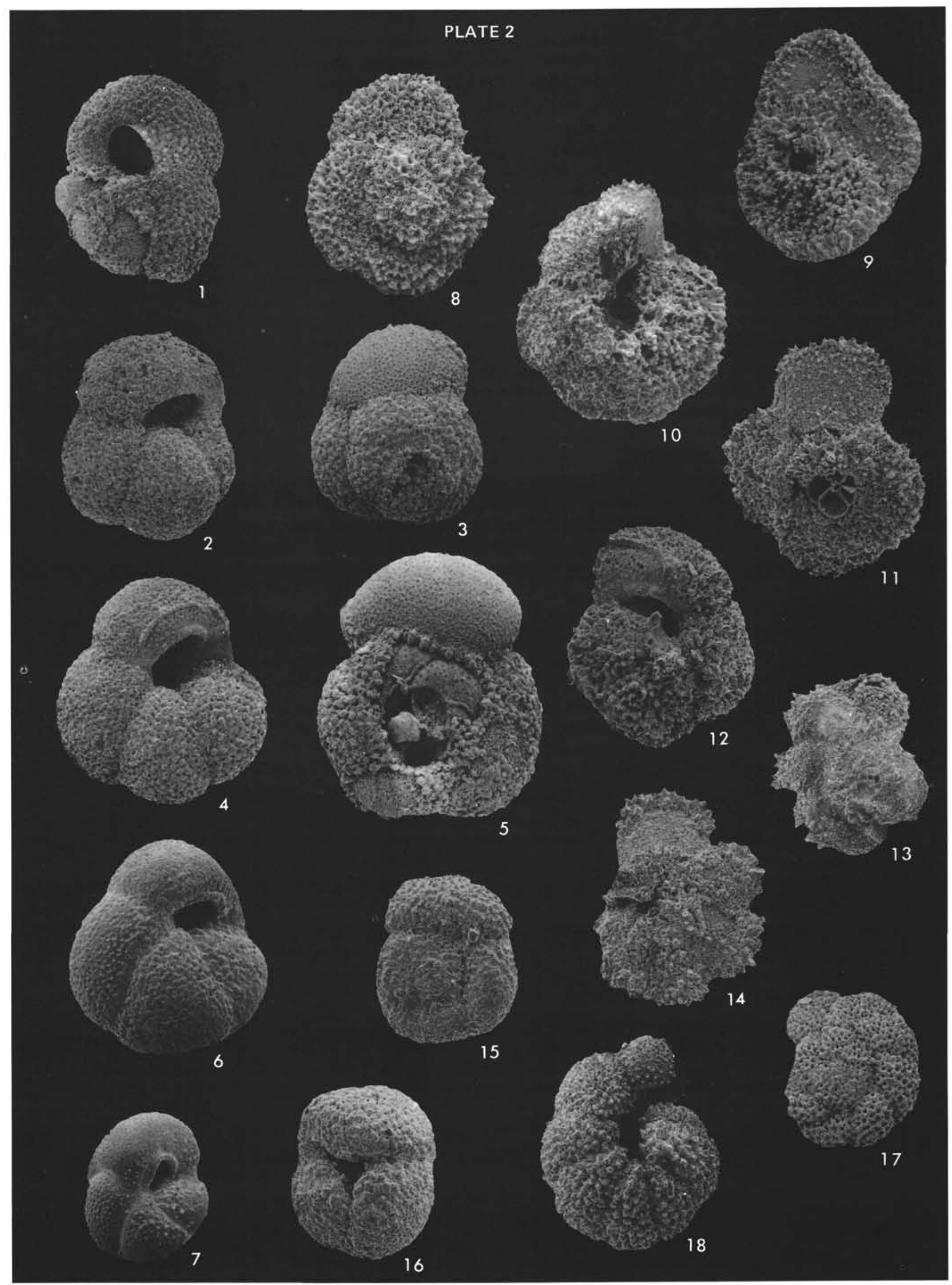




\section{PLATE 3}

All samples from Sample 313-5-0, 2-3 cm; early Oligocene

Figures 1, 2 Globigerina praebulloides Blow, $\times 100$.

1. Spiral view (C 30440 ).

2. Umbilical view (C 30 441).

Figures 3, $4 \quad$ Globigerina galavisi Bermudez, $\times 100$.

3. Spiral view (C 30442 ).

4. Umbilical view (C 30 443).

Figures 5,6 Globigerina ampliapertura Bolli, $\times 100$.

5. Spiral view (C 30444$)$.

6. Umbilical view (C 30445 ).

Figures 7-9 Globigerina gortanii gortanii (Borsetti), $\times 50$.

7. Spiral view (C 30446 ).

8. Umbilical view (C 30447 ).

9. Side view (C 30 448).

Figures 10,11 Globorotalia increbescens (Bandy), $\times 70$.

10. Spiral view (C 30449 ).

11. Umbilical view (C 30450$)$.

Figure 12 Globigerina praesaepis Blow, $\times 100$.

Umbilical view (C 30 451).

Figures 13, 14 Pseudohastigerina barbadoensis Blow. $\times 200$.

13. Spiral view (C 30 452).

14. Side view (C 30 453).

Figures 15, 16 Cassigerinella chipolensis (Cushman and Ponton). $\times 200$.

15. Spiral view (C 30454$)$.

16. Umbilical view (C 30455$)$.

Figures 17, 18 Globigerina venezuelana Hedberg, $\times 50$.

17. Spiral view (C 30456 ).

18. Umbilical view (C 30 457).

Figures 19, 20 Globigerina tripartita Koch, $\times 50$.

19. Spiral view (C 30458 ).

20. Umbilical view (C 30459 ).

Figures 21, 22 Globigerina tapuriensis Blow and Banner, $\times 50$.

21. Spiral view (C 30 460).

22. Umbilical view (C 30461 ).

Figure 23 Globigerinita unicavus (Bolli, Loeblich, and Tappan). $\times 50$.

Umbilical view (C 30 462). 
PLATE 3
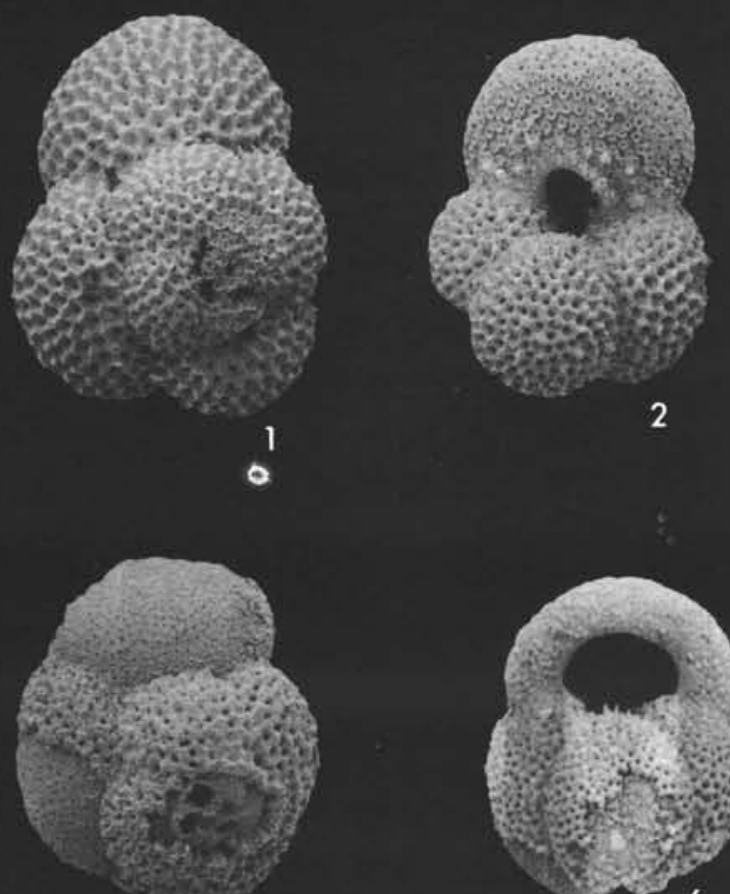

5
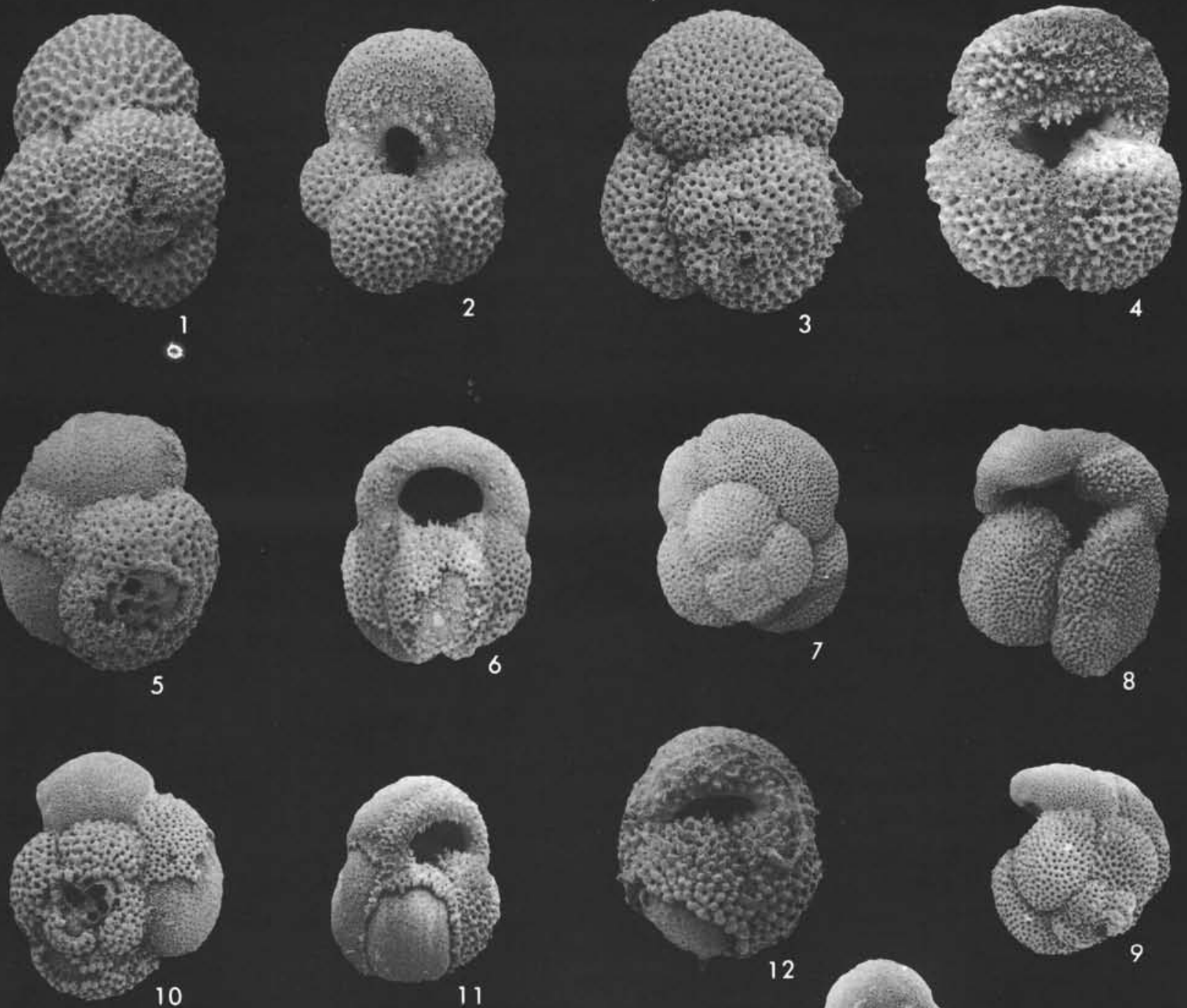

11
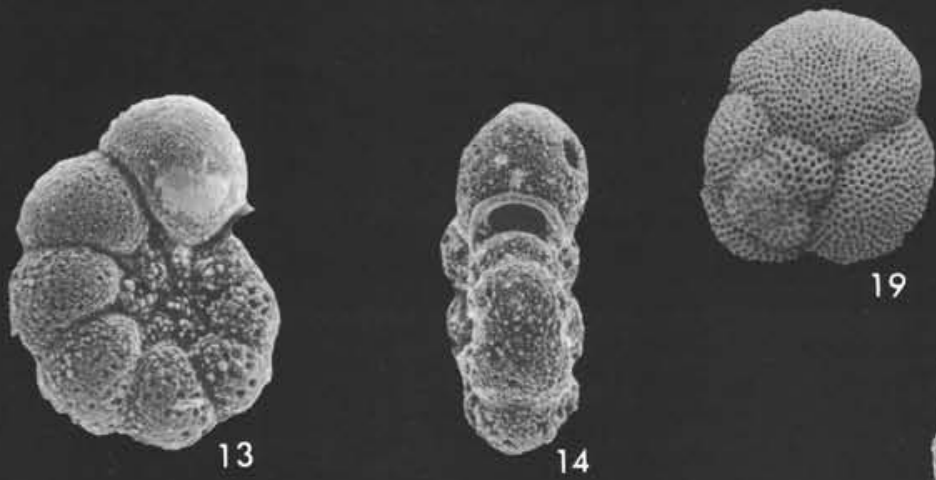

12

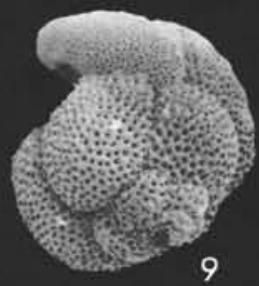

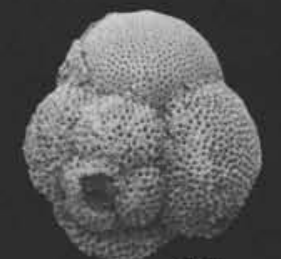

17

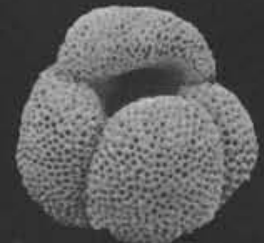

18

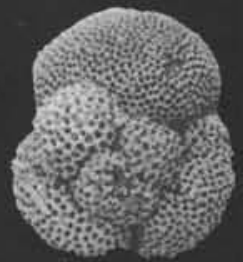

21

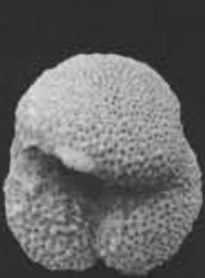

15

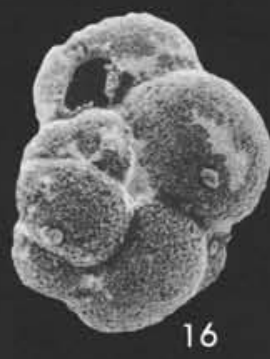

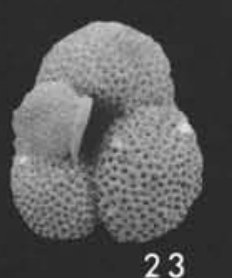




\section{PLATE 4}

Figures 1, 2 Globigerinatheka subconglobata subconglobata (Shutskaya), $\times 70$.

Sample 313-7, CC. Globorotalia lehneri Zone; middle Eocene.

1. Spiral view (C 30 463).

2. Umbilical view (C 30464 ).

Figures 3,4 Globigerinatheka mexicana mexicana (Cushman), $\times 100$.

Sample 305-10, CC. Globorotalia lehneri to Truncorotaloides rohri Zone; middle Eocene.

3. Spiral view (C 30 465).

4. Umbilical view (C 30466 ).

Figure $5 \quad$ Globigerinatheka mexicana barri (Broennimann, $\times 100$.

Sample 305-10-5, 18-20 cm. Globorotalia lehneri to Truncorotaloides rohri Zone; middle Eocene. Specimen with three bullae (C 30 467).

Figures 6,7 Globigerinatheka index index (Finlay), $\times 50$.

Sample 305-10-2, 18-20 cm. Globigerinatheka semiinvoluta Zone; late Eocene.

6. Side view (C 30468 ).

7. Umbilical view (C 30469 ).

Figure $8 \quad$ Globigerinatheka index rubriformis (Subbotina), $\times 50$.

Sample 313-7, CC. Globorotalia lehneri Zone; middle Eocene. Umbilical view (C 30 470).

Figures 9, 10 Globigerinatheka index tropicalis (Blow and Banner), $\times 50$.

Sample 305-10-2, 18-20 cm). Globigerinatheka semiinvoluta Zone; late Eocene.

9. Spiral view (C 30471 ).

10. Spiral view (C 30 472).

Figures 11, 12 Globigerinatheka curryi Proto-Decima and Bolli, $\times 75$.

Sample 313-7, CC. Globorotalia lehneri Zone; middle Eocene.

11. Spiral view (C 30 473).

12. Umbilical view (C 30474$)$.

Figures 13, 14 Globigerinatheka euganea Proto-Decima and Bolli, $\times 75$.

Sample 313-5-1, 5-8 cm. Orbulinoides beckmanni Zone; middle Eocene.

13. Spiral view (C 30 475).

14. Umbilical view with one aperture partially covered by a bulla (C 30476 ).

Figures 15, 16 Orbulinoides beckmanni (Saito), $\times 75$.

Sample 313-5-1, 5-8 cm. Orbulinoides beckmanni Zone; middle Eocene.

15. Side view. Large sutural apertures between early whorl and final chamber (C 30 477).

16. id (C 30 478).

Figures 17, 18 Globigerinatheka semiinvoluta (Keijzer), $\times 200$.

Sample 305-9, CC. Globigerinatheka semiinvoluta Zone; late Eocene.

17. Specimen with one aperture in last chamber (C 30479$)$.

18. Specimen with two apertures in last chamber (C 30480 ).

Figures 19, 20 Globigerinatheka subconglobata luterbacheri Bolli, $\times 75$.

Sample 305-9, CC. Globigerinatheka semiinvoluta Zone; late Eocene.

19. Spiral view (C 30481 ).

20. Umbilical view (C 30 482). 


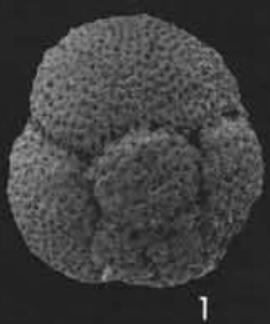

\section{PLATE 4}
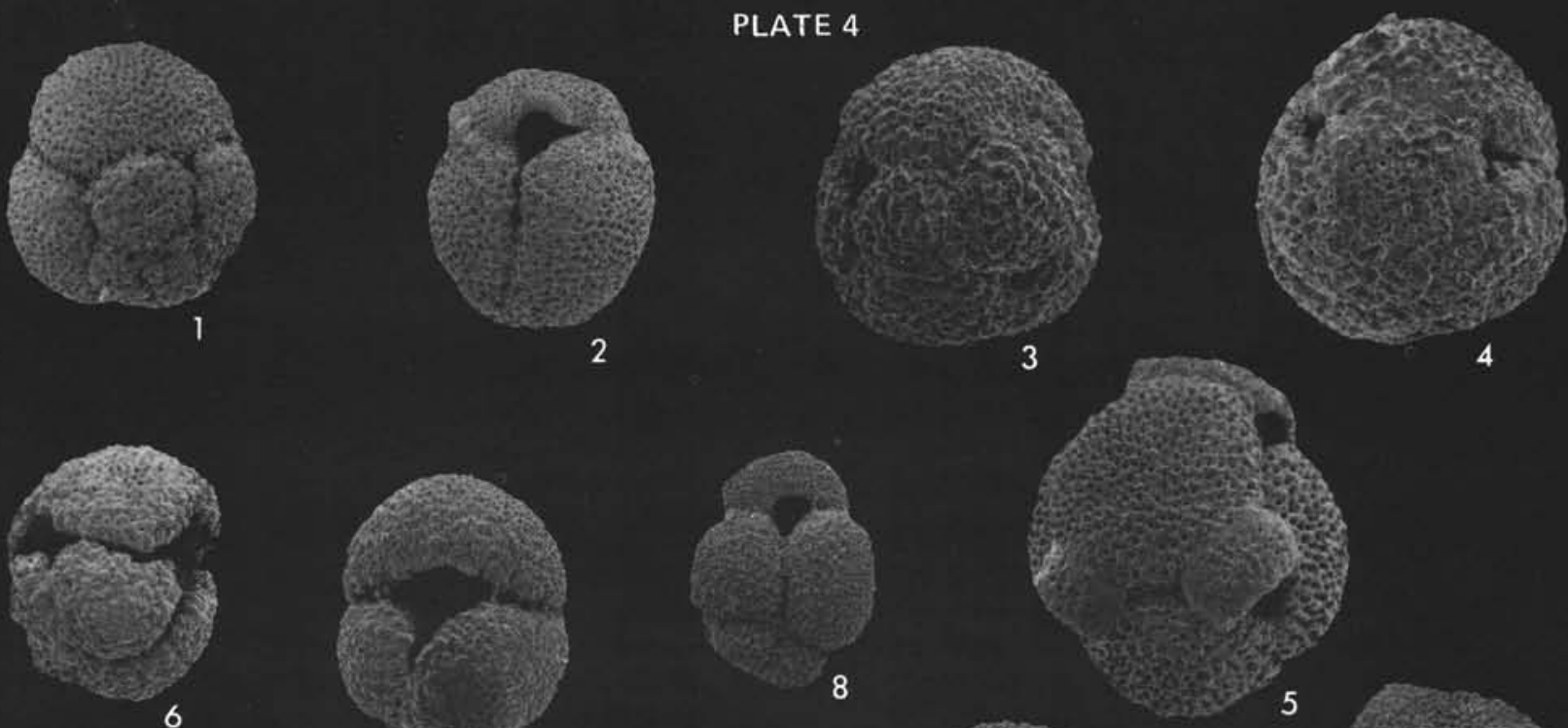

8
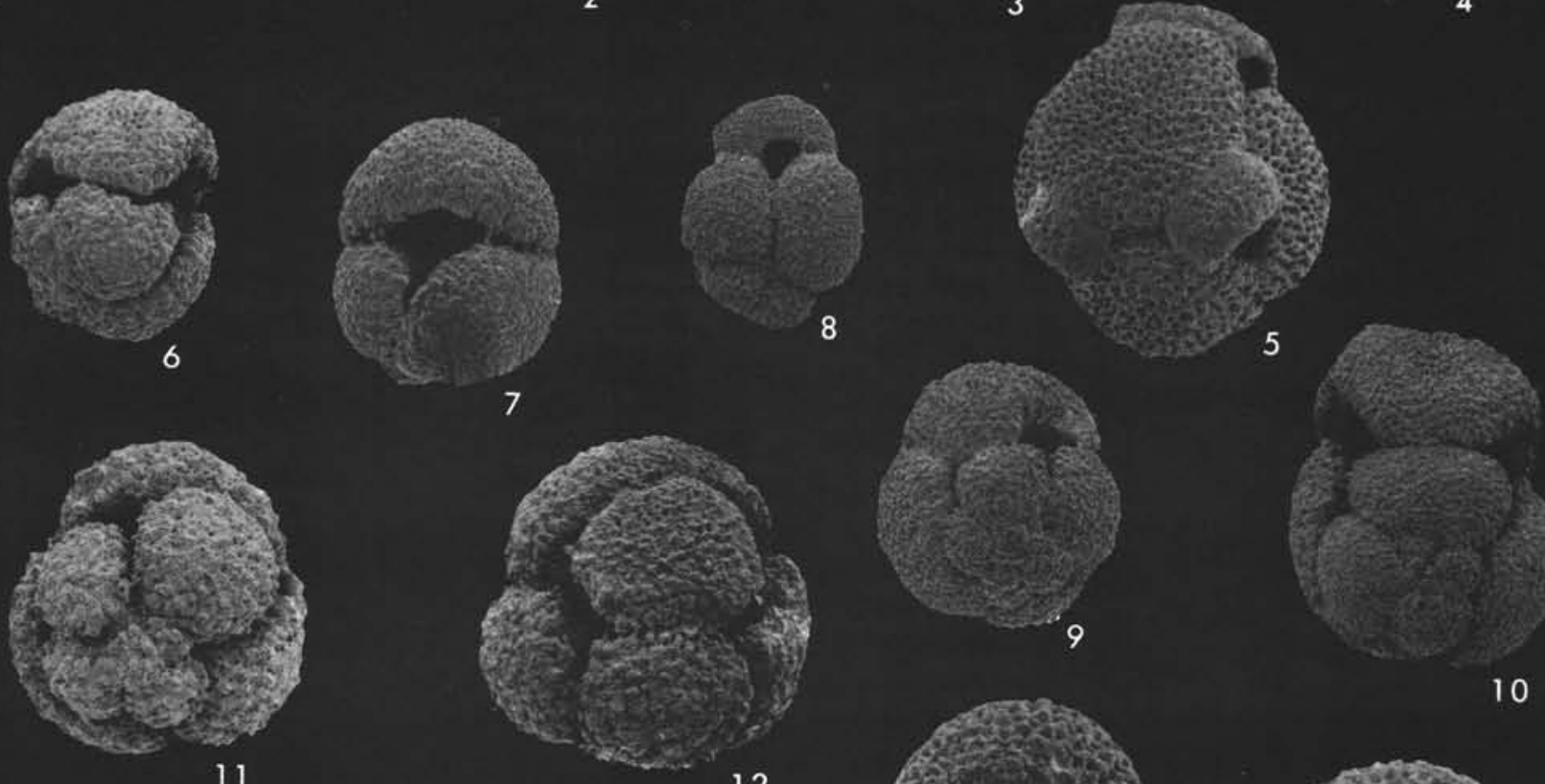

11
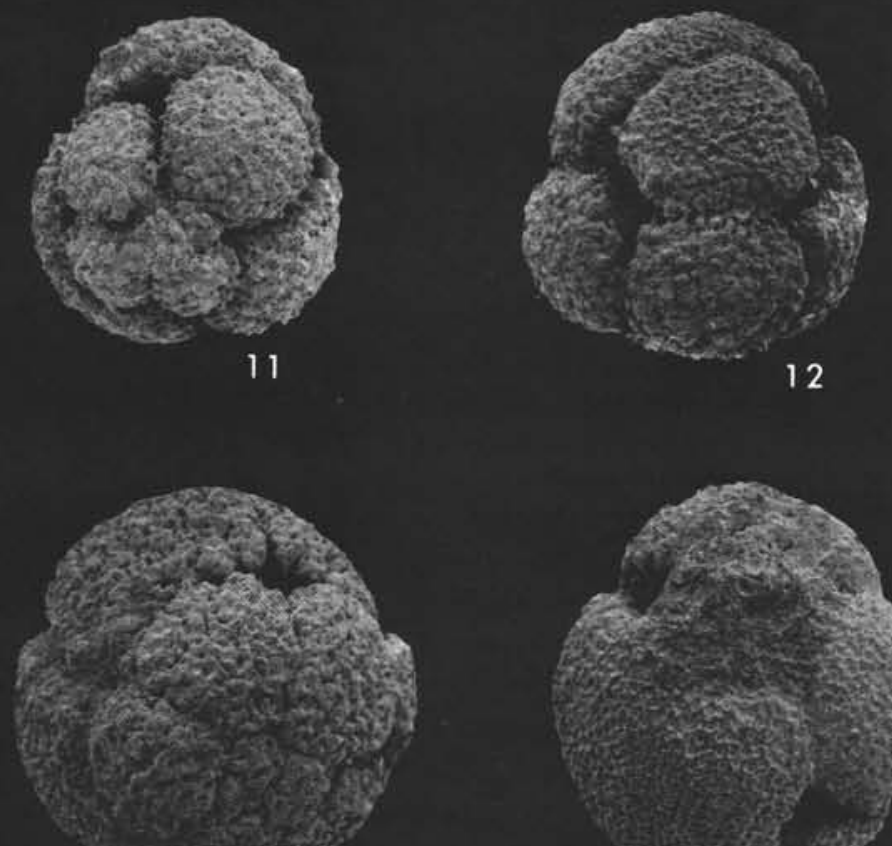

13
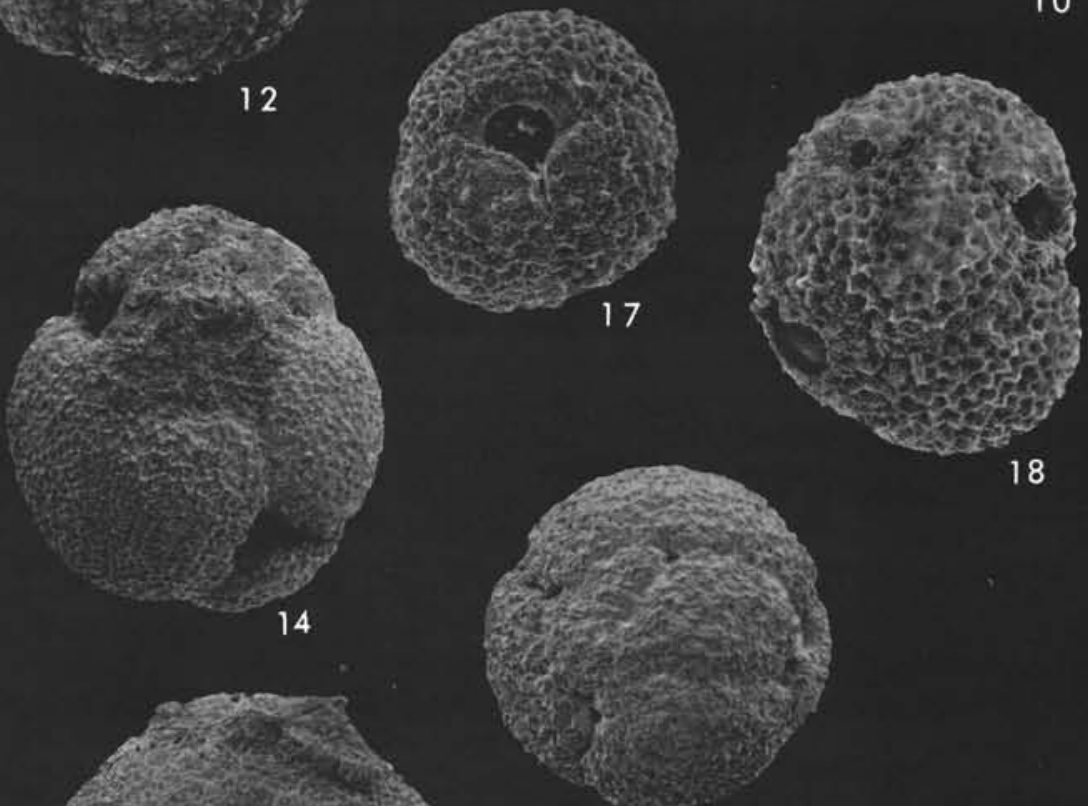

18

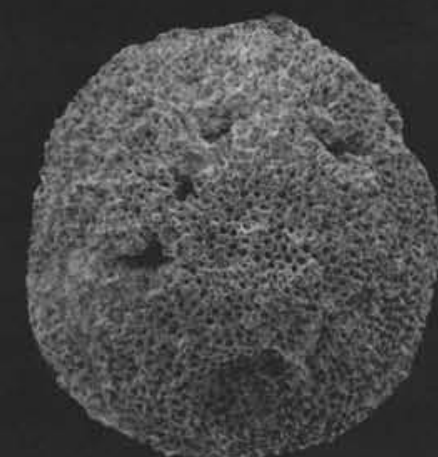

15

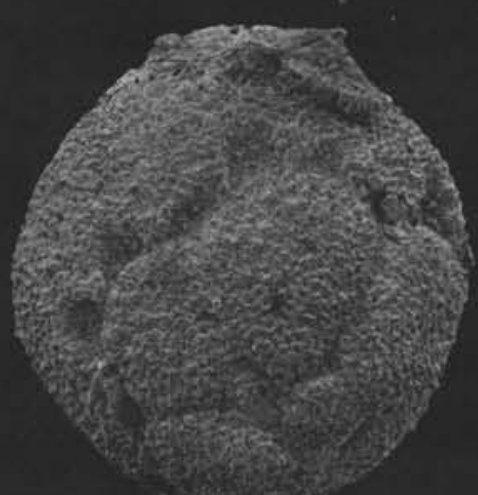

16
19

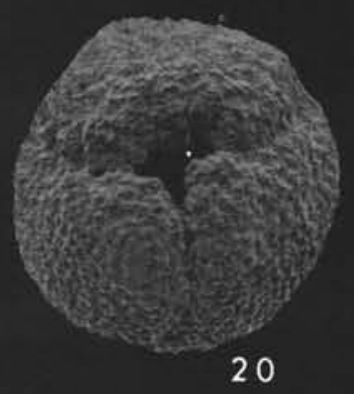




\section{PLATE 5}

Specimens corroded by effects of dissolution, showing enlarged pores, more pronounced spines, and enhanced umbilicus.

Figures 1,2 Globorotalia spinuloinflata (Bandy), $\times 100$. Sample $310-11-1,120-122 \mathrm{~cm}$; early to middle Eocene.

1. Spiral view (C 30483 ).

2. Umbilical view (C 30484 ).

Figures 3,4 Globigerina linaperta Finlay, $\times 100$.

3. Sample 313-7, CC. Globorotalia lehneri Zone; middle Eocene. Spiral view (C 30 485).

4. Sample 310-11-1, 120-122 cm; early to middle Eocene. Umbilical view (C 30 486).

Figures 5-11 Globigerina senni Beckmann.

5-8. Sample 305-10, CC. Globorotalia lehneri to Truncorotaloides rohri zones; middle Eocene.

5. $\times 100$. Spiral view (C 30487$)$.

6. Umbilical view, $\times 100$ (C 30 488).

7. Umbilical view, $\times 300$. Detail of Figure 6 .

8. Umbilical view, $\times 1000$. Detail of Figure 6, showing a well preserved coccolith on the corroded test of the Globigerina.

9-11. Sample 313-5-2, 123-125 cm. Globorotalia lehneri to Orbulinoides beckmanni Zone; middle Eocene.

9. Umbilical view, $\times 50$ (C 30489 ).

10. Umbilical view, $\times 50$ (C 30490 ).

11. $\times 500$. Detail of Figure 10 , showing well preserved coccoliths between the corroded crystals of the test of the Globigerina.

Figures 12-14 Globorotalia lehneri Cushman and Jarvis. Sample 313-7, CC. Globorotalia lehneri Zone; middle Eocene.

12. Spiral view, $\times 70$ (C 30491$)$.

13. $\times 400$. Detail of Figure 12, showing pronounced spines.

14. $\times 200$. Detail of Figure 12, showing the embryonic chambers, visible by the corrosion of the initial spire.

Figure $15 \quad$ Globorotalia increbescens (Bandy), $\times 70$. (C 30 492).

Sample 313-5-0, 2-3 cm; early Oligocene. Spiral view, showing a hole in the last chamber, the initial spire corroded and the crystals of the sutures preserved against dissolution.

Figures 16-20 Globigerina eocaena Guembel.

Sample 305-10, CC. Globorotalia lehneri to Truncorotaloides rohri Zone; middle Eocene.

16. Umbilical view, $\times 100$. (C 30493 ).

17-20. Spiral view (C 30494 ), showing the surface of the test covered by funnel-shaped pustules.

17. $\times 100$.

18. $\times 250$.

19. $\times 1500$.

20. $\times 2500$. 

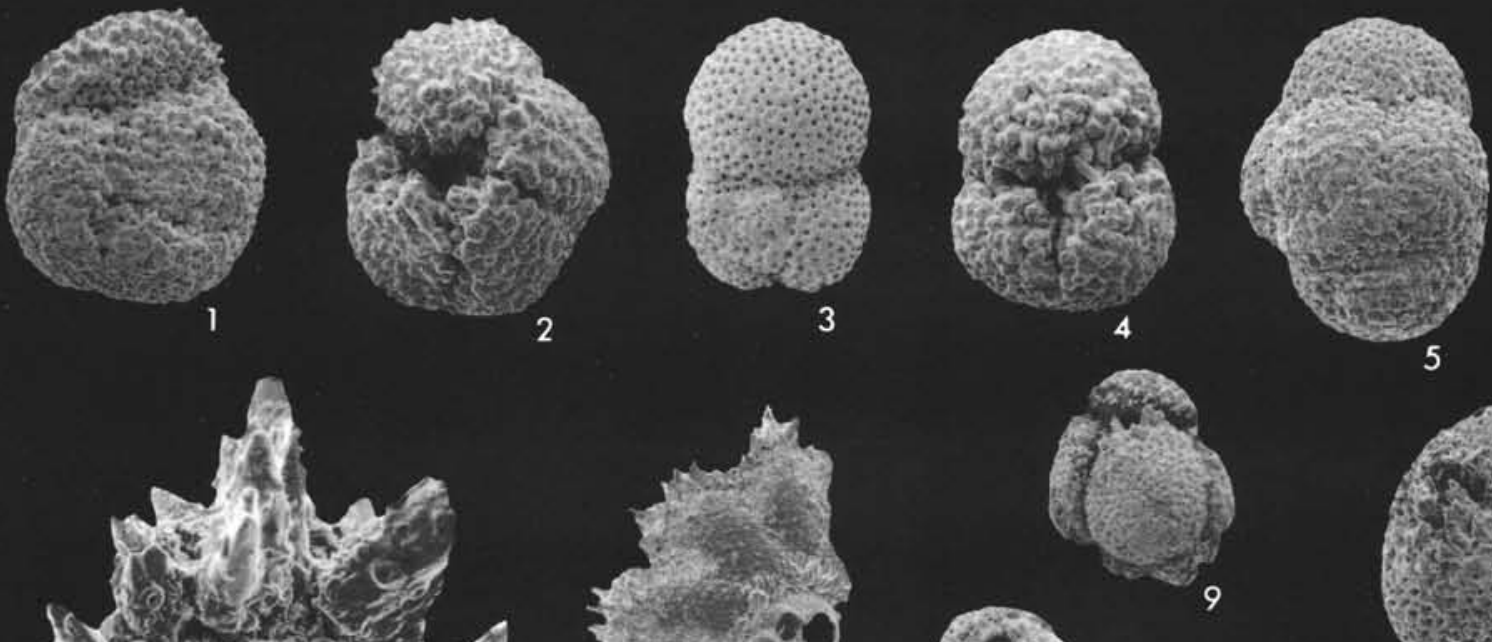

16. 50 .

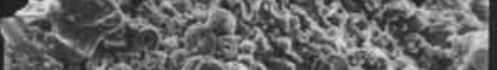
now 55 ?

in

13

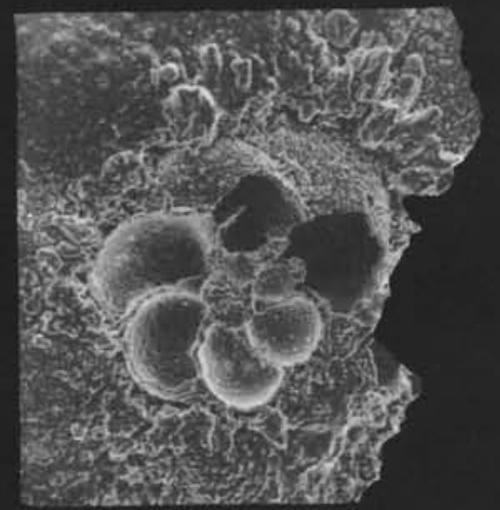

14

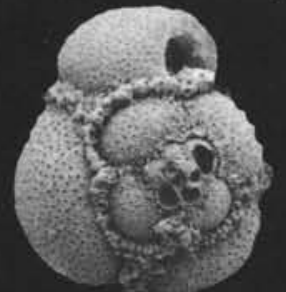

15

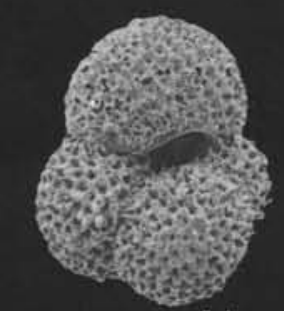

16

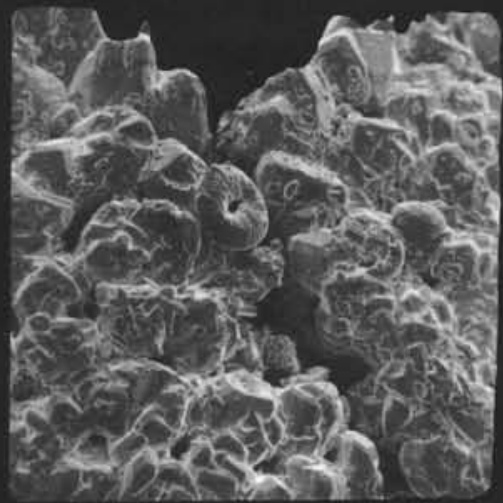

11

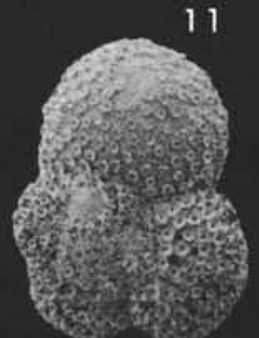

17

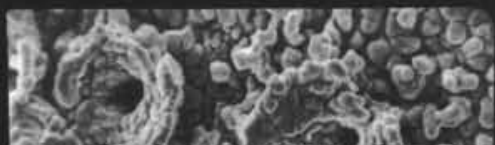

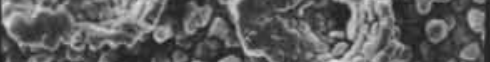

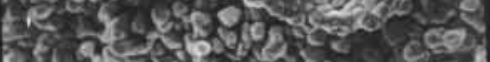

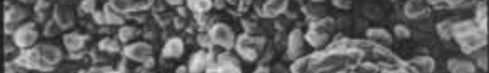

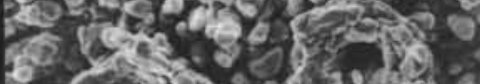
8 Som

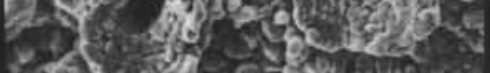

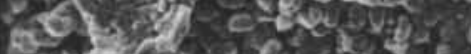

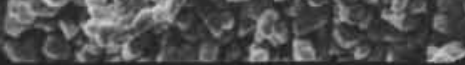

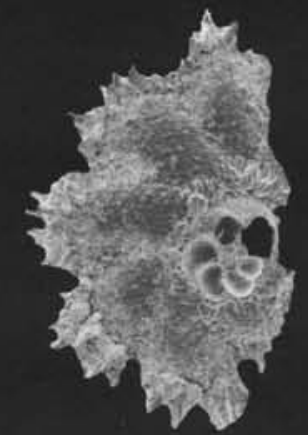

12

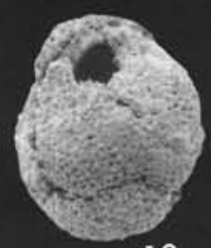

10
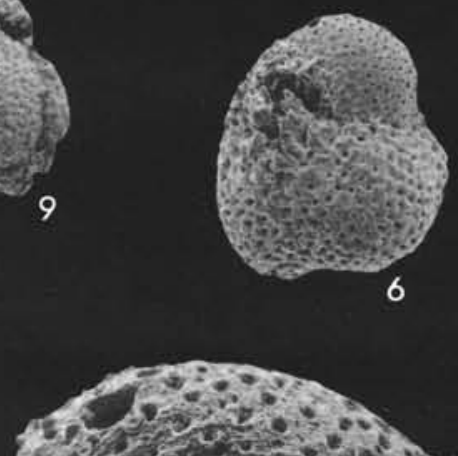

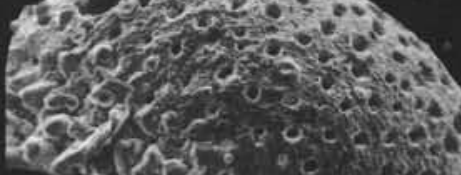
be eforing

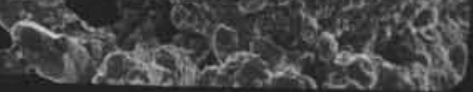
7
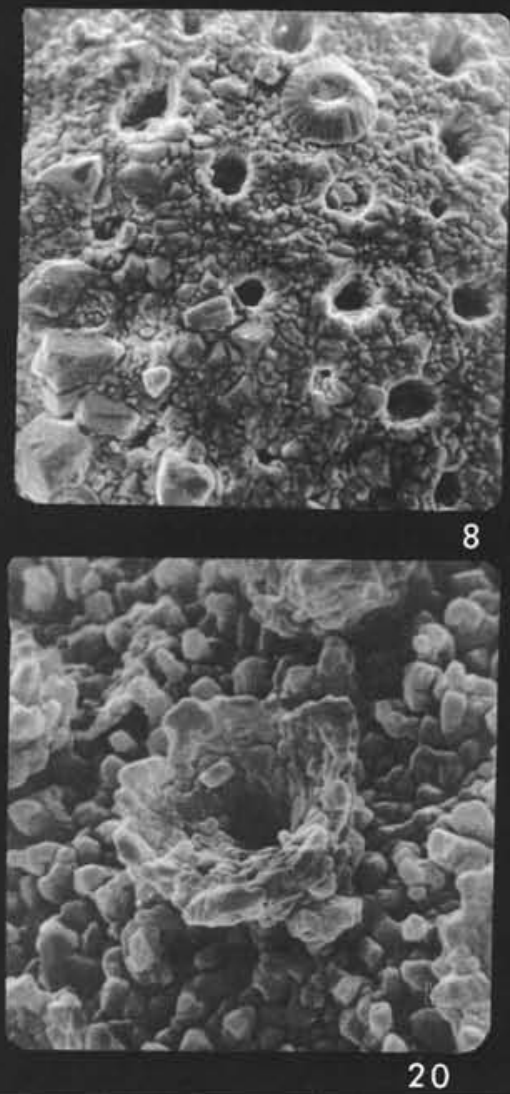